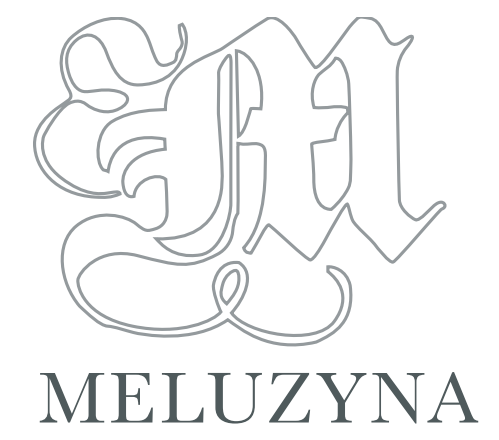

ISSN 2449-7339

1 (2014)

PRZEKROJE I ZBLIŻENIA

\author{
Kamila Buszka ${ }^{\star}$ \\ Uniwersytet Śląski w Katowicach
}

\title{
Pomiędzy tradycją a nowatorstwem. Rola postaci kobiecych w świecie przedstawionym eposu Torquata Tassa Gofred abo Jeruzalem wyzwolona (w przekładzie Piotra Kochanowskiego)
}

Tradycyjnie rola przewodników po epopeicznym świecie przypada bohaterom - herosom, półbogom, ale także władcom i rycerzom. Według Izydora z Sewilli herosi zasługują na uwiecznienie w ludzkiej pamięci, gdyż ich czyny są niezwykłe i świadczą o mądrości i męstwie (sapientia et fortitudo $)^{1}$. Teresa Michałowska zauważa, że w dawnych wiekach do najważniejszych cech epickiego bohatera zaliczano wspaniałość ducha (magnanimitas), męstwo (fortitudo) oraz wiedzę i mądrość (prudentia), którą heros zdobywa poznając świat, a która współgra z humanistyczną ideą „poszukiwacza prawdy” ${ }^{2}$. Typowy heros szczycił się pochodzeniem ze szlachetnego albo boskiego rodu, co nierzadko wiązało się także z nadzwyczajnymi zdolnościami i wielką wytrzymałością - wszak był on predestynowany do realizowania zadań przekraczających siły zwykłego śmiertelnika. Dążył do zdobycia sławy, mógł być mężem stanu lub wodzem³. Fabuła eposu powinna natomiast rozwijać się wokół jednej wybitnej postaci, której doskonałość ukazano na tle wydarzeń wojennych.

Artykuł jest próbą odpowiedzi na pytanie, czy w tym skonwencjonalizowanym schemacie epickiego bohatera znajdzie się miejsce dla kobiet, i czy mogą one wystąpić w roli herosów, czy też pozostaje im jedynie rola biernych obserwatorek zdarzeń. Analizie zostaną poddane postaci trzech głównych bohaterek Jerozolimy wyzwolonej - Kloryndy, Armidy i Erminii - których

\footnotetext{
* e-mail autora: kamila_buszka@interia.pl

1 T. Michałowska, Poezja epicka (epica poesis), [w:] eadem, Staropolska teoria genologiczna, Wrocław 1974, s. 84.

2 Ibidem, s. 86.

3 Zob. E.R. Curtius, Literatura europejska i łacińskie średniowiecze, tłum. A. Borowski, Kraków 1997, s. 175-180.
} 
obecność nie tylko dodatkowo ubarwiła wojenne zmagania, lecz także wywarła niemały wpływ na przebieg akcji.

Maciej Kazimierz Sarbiewski, który przedstawił teorię epopei w dziele De perfecta poesi, uważał, że postacie kobiece nie mogą wysuwać się na plan pierwszy. Kobiety mogą co najwyżej wspierać herosa bądź utrudniać mu wykonanie zadania ${ }^{4}$. Wydaje się jednak, że Sarbiewski nie wziął pod uwagę dzieła Torquata Tassa, który w Jerozolimie wyzwolonej przełamał, jak sądzę, antyczny wzór epopeicznych bohaterek. Piotr Kochanowski, dokonując przekładu włoskiego epo$\mathrm{su}^{5}$, próbował przeszczepić na grunt polski to nowatorskie podejście do roli postaci kobiecych w świecie przedstawionym ${ }^{6}$.

Roman Pollak w swojej monumentalnej monografii poświęconej Gofredowi wyróżnia w materii poematu warstwę batalistyczną i romansową. Rozważając kwestie wojny pobożnej, omawia heroiczne czyny Gofreda, Arganta, Rynalda. Mówiąc zaś o miłosnych perypetiach bohaterów, skupia uwagę na Armidzie, Erminii i Kloryndzie ${ }^{7}$. Pomijanie rycerskich dokonań Kloryndy, rozpatrywanie tej postaci wyłącznie w kontekście jej miłości do Tankreda, wydaje się jednak niedostatecznie uzasadnione. Piotr Kochanowski nie opisuje w swoim przekładzie Jerozolimy wyzwolonej miłości Kloryndy do Tankreda. Opowiada wyłącznie o miłości Tankreda do Kloryndy. Tylko raz bohaterka wyznaje rycerzowi swoje uczucia - „Zostań żyw, a wiedz, że się kocham w tobie". Słowa te zostały wypowiedziane pośmiertnie, w sennej wizji Tankreda. Co więcej, dziewczyna dodaje - „Jako się kochać nam w stworzeniu godzi” (pieśń XII, oktawa 93) ${ }^{8}$. Nasuwa się wniosek, że miłosne wyznanie Kloryndy realizuje wzorzec chrześcijańskiej miłości bliź-

4 M.K. Sarbiewski, O poezji doskonałej, czyli Wergiliusz i Homer (De perfecta poesi, sive Vergilius et Homerus), tłum. M. Plezia, oprac. S. Skimina, Wrocław 1954, s. 27.

5 Stanisław Grzeszczuk twierdzi, że o przekładzie Piotra Kochanowskiego właściwie można mówić jak o dziele oryginalnym, odmiennym od włoskiego pierwowzoru, choć z nim związanym. Badacz zauważa, że Gofred jest utworem zespolonym z polską kulturą, językiem, obyczajem, polską problematyką polityczną i moralną (zob. S. Grzeszczuk, „Gofred albo Jeruzalem wyzwolona” Piotra Kochanowskiego. O staropolskiej epopei narodowej, Kraków 1967, s. 3-13). Anna Kalewska podkreśla, że utwór Tassa w przekładzie Kochanowskiego stał się wzorem polskiego etosu i eposu rycerskiego (zob. A. Kalewska, „Gofred” Tassa-Kochanowskiego - epos o rycerzu pobożnym, [w:] Z ducha Tassa. Ksiega pamiątkowa sesji naukowej w czterechsetlecie śmierci pisarza (1544-1595), red. R. Ocieczek, B. Mazurkowa, Katowice 1998, s. 108-112). Także Roman Pollak poruszał kwestię oryginalności utworu Kochanowskiego, zwracając uwagę na dostosowanie treści do polskich realiów. Badacz uznał jednak, że pisarz nie poradził sobie z charakterami kobiecymi - wizerunek Erminii „przełzawił” i „przemdlił”; trudno było mu przełożyć na język polski wyrafinowane wyznania miłosne Armidy. Najlepiej spolszczył Kloryndę, ponieważ ta bohaterka miała w sobie najwięcej cech męskich (zob. R. Pollak, „Goffred” Tassa-Kochanowskiego, Wrocław 1973, s. 68-86, 121-132). Przekład Kochanowskiego odegrał w polskiej poezji epickiej taką samą rolę, jak w innych krajach podobne utwory oryginalne. Dlatego też, idąc za przykładem Pollaka, Kalewskiej i innych, decyduję się mówić o dziele „Tassa-Kochanowskiego”, kładąc w ten sposób nacisk na znaczenie tego tekstu dla literatury polskiej. Jednocześnie podkreślam, że wizerunek postaci kobiecych jest analizowany na podstawie przekładu Kochanowskiego, a nie oryginału włoskiego.

6 Nawet po ukazaniu się Jerozolimy wyzwolonej rola kobiet w polskiej epice heroicznej nie była znacząca. Postaci Kloryndy, Erminii i Armidy inspirowały późniejszych poetów, m.in. w epoce romantyzmu (zob. J. Krzyżanowski, „Jeruzalem wyzwolona” Tassa-Kochanowskiego a romantycy polscy, „Pamiętnik Literacki” 1966, z. 4, s. 365-409).

7 Zob. R. Pollak, Goffred Tassa-Kochanowskiego..., s. 121-132.

8 T. Tasso, Gofred abo Jeruzalem wyzwolona, tłum. P. Kochanowski, oprac. S. Grzeszczuk, przypisy R. Pollak, Warszawa 1968, s. 438. Wszystkie cytaty za tą edycją, do tekstu odwołuję się wskazując na pieśń i oktawę. 
niego, ideę miłości świętej, a nie cielesnej i zmysłowej. Bohaterka nie czuła gorących uczuć dla rycerza - pojawiły się one dopiero po przyjęciu chrześcijaństwa.

Miłość Tankreda do Kloryndy stała na drodze jego powołania do walki z poganami, zaślepiła rycerza i zagroziła jego sławie. Śmierć dziewczyny umożliwiła mu powrót do grona tych, którzy nieustannie walczą o Chrystusową sprawę. Podobny motyw miłości ziemskiej, która zagraża pokrzyżowaniem planów Stwórcy, pojawia się u Ariosta. Orland płaci szaleństwem za swoje uczucia do poganki, Tankred - nieutulonym żalem po jej śmierci. Na szczęście dla Tassowskiego bohatera Pustelnikowi udaje się przekonać rycerza do otarcia łez i przyjęcia wyroków Bożych jako daru, a nie kary:

Twe utrapienie Bóg wieczny na niebie

Sam na cię posłał, [...]

I do dobrego rycerza cię wiedzie

Chrystusowego pierwszej powinności,

Którą-ś opuścił, o głupi Tankredzie,

Kwoli niewiernej poganki miłości.

I teraz na cię z lekką pomstą jedzie,

Z lekkim karaniem za twe nieprawości

I uleczyć cię chce przez cię samego,

A ty nie widzisz daru tak zacnego?

(pieśń XII, oktawy 86-87)

Również Klorynda, ukazując się rycerzowi we śnie i zapewniając go o swoim oddaniu, przyczynia się do tego, że jego heroiczne przeznaczenie może się wypełnić. Bohaterka była potrzebna Tankredowi, by ten, przezwyciężywszy własne namiętności, stał się „lepszym” rycerzem Chrystusowym, przedkładającym sprawy boskie nad ludzkie. Trzeba jednak zaznaczyć, że w związku Kloryndy i Tankreda to niewiasta nigdy nie uległa namiętnościom. Słabszy wobec uczuć okazał się mężczyzna9 .

Wątek miłosny nie służy wyłącznie ukazaniu triumfu Amora niebiańskiego nad ziemskim. Jest jedynie ogniwem w łańcuchu zdarzeń, zmierzających ku nawróceniu poganki. Jej męka ma głęboki wymiar eschatologiczny, dowodzi nieograniczonej mocy Stwórcy. Janusz K. Goliński zauważył, że bohaterka zginęła z ręki kochającego ją mężczyzny, by mogła narodzić się dla Boga ${ }^{10}$. Znamienne, że to właśnie Tankred zadał ranę, która uśmierciła Kloryndę. Symboliczna śmierć dotknęła Amora ziemskiego. Nie przetrwał on starcia z niebiańską miłością, która zachwiała fundamentem pogańskiej wiary bohaterki. Z drugiej strony, należy pamiętać, że Klorynda niejako od urodzenia była przeznaczona do życia w wierze Chrystusowej, dlatego uczucia, jakie ży-

9 Tankred zastyga w zachwycie, gdy dostrzega postać Kloryndy, przez co nie stawia się na umówiony pojedynek z Argantem (ibidem, s. 214-215; pieśń VI, oktawy 26-27), rozpacza po śmierci Kloryndy, nie myśli o wojnie ani o swych rycerskich obowiązkach, rozważa nawet popełnienie samobójstwa (ibidem, s. 431-435; pieśń XII, oktawy 73-83). Natomiast Kloryndzie uczucia nie przeszkodziły w walce z chrześcijanami, nawet w obliczu miłości i śmierci nie schodzi z raz obranej drogi (zob. scenę pojedynku Tankreda i Kloryndy - ibidem, s. 424-429; pieśń XII, oktawy 52-68).

10 J.K. Goliński, Między niebem a piekłem. „Wojna pobożna” bohaterów Tassa - Kochanowskiego, [w:] Z ducha Tassa..., s. 139. 
wił do niej rycerz, nie można uznać za przyczynę jej nawrócenia. Do przyjęcia chrześcijaństwa skłoniło bohaterkę raczej poczucie, iż oto wypełniają się słowa św. Jerzego:

Już czas nadchodzi niezahamowany,

Że się Klorynda rozstać ma z żywotem

[...] gwałtem przedsię ona

Pójdzie do nieba i będzie zbawiona [...].

(pieśń XII, oktawa 39)

Obecne w dawnych wiekach myślenie o kobietach w kategoriach „słabszego naczynia” lub „nieudanego mężczyzny”"11 pozbawiało je pewności siebie. Kobieta była przede wszystkim żoną i matką. Rola żony często wymagała, aby towarzyszyła ona mężowi podczas wyprawy krzyżowej, a choć bywało, że kobiety walczyły zbrojnie, to jednak głównym ich obowiązkiem stawała się opieka nad rannymi czy zaopatrywanie obozu w wodę ${ }^{12}$. Uważano, że płeć piękna powinna godzić się z patriarchalnym porządkiem świata13. Zgodnie $\mathrm{z}$ takimi poglądami została stworzona Tassowska bohaterka literacka. A jednak Klorynda pragnie rycerskiej sławy i udowodnienia sobie, ale także towarzyszom walk, że jest nie mniej mężna od Arganta czy Solimana:

Ej, toć się wżdy dziś dobrze popisali

Z mężnym Sułtanem Argant natarczywy,

Kiedy sami dwaj tylko wypadali

Na wszystko wojsko i robili dziwy.

A o mnie co też będą powiadali?

»Użyła - prawi - z daleka cięciwy

Dosyć szczęśliwie«. To te będą mowy

Cóż, czy nie mogą więcej białegłowy?

(pieśń XII, oktawa 3)

Jednakże po raz kolejny zwycięża tu tradycyjny schemat ról przypisanych płciom, bohaterka przyjmuje rolę pomocnika, a nie inicjatora walk. Choć to ona obmyśliła plan podejścia pod chrześcijański obóz i podpalenia wieży, która zagraża Jerozolimie, pozwala Argantowi przejąć dowództwo, a własne zasługi umniejsza, mówiąc królowi: „Argant tę wieżę spalić chce i na tem / Miejscu czyni-ć tę obietnicę głośną. / Ja przy nim będę [...]” (pieśń XII, oktawa 10). Bez względu na to, zdanie Kloryndy wśród rycerstwa jest poważane i respektowane, bohaterka cieszy się opinią nieustępliwej wojowniczki, nikt nie sprzeciwia się jej rozkazom, a król Jerozolimy mianuje ją hetmanem. Chyba po raz pierwszy w eposie kobieta dostępuje zaszczytu dowodzenia armią złożoną z mężczyzn. Bowiem Kamilla, bohaterka Eneidy Wergiliusza, której postać można uznać za jedną z pierwszych realizacji motywu walecznej niewiasty, nigdy nie przewo-

11 M. Bogucka, Białogłowa $w$ dawnej Polsce. Kobieta $w$ społeczeństwie polskim w XVI-XVIII wieku na tle porównawczym, Warszawa 1998, s. 116, 118.

12 R. Pernoud, Kobieta w czasach wypraw krzyżowych, tłum. I. Badowska, Gdańsk 2002, s. 18.

13 Zob. P. Brown, Ciało i społeczeństwo. Mężczyźni, kobiety i abstynencja seksualna we wczesnym chrześcijaństwie, tłum. I. Kania, Kraków 2006, s. 27-29. 
dziła mężczyznom, lecz jedynie walecznemu gronu kobiet ${ }^{14}$. Jednak obraz Kloryndy-wojownika budzi pewne zastrzeżenia. Nie tylko dlatego, że bohaterka, będąc poganką, nie wpisuje się w zachodni wzorzec rycerza, którego system etyczny ściśle wiąże się z wartościami chrześcijańskimi ${ }^{15}$. Choć nikt nie może odmówić tej postaci męstwa i waleczności, to jednak jej odwaga nigdy nie posunęła się do, jak mówi Maria Ossowska, „[...] łamania elementarnych zasad strategii, co z kolei pociąga za sobą bardzo często zgubę rycerza i masakrę wszystkich jego ludzi”"16. Klorynda nie jest Rolandem, nie musi wygrać za wszelką cenę. Stojąc przed przeważającymi siłami wroga, rozumnie kalkulując szanse, bez wahania ucieka. W przypadku Kloryndy rezygnuje więc autor $\mathrm{z}$ idealizacji postawy bohaterki, nie wylicza jej czynów wojennych. Unika dzięki temu schematyczności w charakterystyce bohaterki. Natomiast w konstrukcji postaci Gofreda epik postępuje zgodnie z istniejącą konwencją; działania bohatera doskonale wpisują się w określony typ zmitologizowanej narracji batalistycznej, gdzie każdy szczegół bitwy podporządkowywano nadrzędnemu celowi, jakim była walka Dobra ze Złem" ${ }^{17}$.

Scena, w której bohaterce, po zniszczeniu wieży oblężniczej, grozi pojmanie, uwidacznia przede wszystkim pragmatyzm Kloryndy. By nie dostać się w ręce wroga, używa fortelu - udając rycerza Chrystusowego, miesza się z tłumem i w ten sposób unika demaskacji. Jej postawę można przyrównać do postawy Odyseusza, który także, chcąc osiągnąć cel, nieraz podszywał się pod kogoś innego. Choć Odysa uznawano za bohatera heroicznego, to Achilles, mimo że i jemu zdarzało się udawać inną osobę, był w Iliadzie wzorcowym wojownikiem ${ }^{18}$. Klorynda wykazuje cechy heroiczne, jednak ktoś inny odgrywa w Jerozolimie wyzwolonej rolę modelowego bohatera.

Najpoważniejszym mankamentem w rycerskiej postawie Kloryndy jest niezbyt aktywne zabieganie o palmę pierwszeństwa. Wspomniana już wcześniej sytuacja, w której bohaterka oddaje inicjatywę Argantowi, to najlepszy tego przykład. Z drugiej strony, sława nie jest jej obojętna. Rozważnie dobiera przeciwników, „Przedniejszych wodzów, nie gminu podłego, / Strzegąc się, harda, celu niegodnego" (pieśń XI, oktawa 41). Jednocześnie świadoma, że o chwale rycerza decydował sposób walki, a niekoniecznie jej wynik ${ }^{19}$, nie wykorzystuje uczucia, jakim darzy ją Tankred, by przerwać śmiertelny dla niej pojedynek. Wręcz przeciwnie, nie tylko nie wyjawia mu swego imienia, ale specjalnie podsyca jego gniew, doprowadzając do pogorszenia własnej sytuacji, poprzez co, jak twierdzi Ossowska, odwaga rycerza jeszcze bardziej się uwi-

\footnotetext{
14 Motyw virago znany był już starożytnym. Grecy snuli opowieści o córkach boga wojny Aresa, o Amazonkach, którymi rządziły królowe. Jedna z nich, Pentesileja, rzuciła wyzwanie samemu Achillesowi i, choć została zabita, na stałe zapisała się w pamięci Greków. Co ciekawe, Achilles dowiedział się, iż walczył z kobietą dopiero po jej śmierci (zob. Pentesileja; Atalanta [w:] V. Zamarovsky, Bogowie i herosi mitologii greckiej i rzymskiej, tłum. J. Illg, L. Spyrka, J. Wania, Katowice 2003, s. 363-364).

15 Zob. F. Cardini, Wojownik i rycerz, [w:] Człowiek średniowiecza, red. J. Le Goff, tłum. M. Radożycka-Paoletti, Warszawa 2000, s. 104-108.

16 M. Ossowska, Ethos rycerski i jego odmiany, Warszawa 1986, s. 73.

17 Zob. P. Żmudzki, Władca i wojownicy. Narracje o wodzach, drużynie i wojnach w najdawniejszej historiografii Polski i Rusi, Wrocław 2009, s. 22.

18 O bohaterach Homeryckich zob. m. in. B. Bednarek, Epos europejski, Wrocław 2001, s. 20-43.

19 M. Ossowska, Ethos rycerski..., s. 77.
} 
dacznia ${ }^{20}$. Bohaterka pragnie oddać życie w chwalebnej walce, z dumą stawiając czoła przeciwnikowi, a nie błagając o litość. Tym samym śmierć Kloryndy staje się kolejną realizacją motywu rycerskiej śmierci. Jednak mimo że bohaterka umiera, nie ponosi klęski. Zarówno Kamilla z Eneidy, jak i Klorynda giną niejako z woli bogów, lecz inne są okoliczności i motywacja ich śmierci. Kamilla, podstępnie raniona przez Arrunsa za zgodą Feba ginie, bo tak zadecydował los, względnie Apollo, który wysłuchał modłów wojownika ${ }^{21}$, toteż śmierć Wergiliuszowej bohaterki nie niesie z sobą żadnych dodatkowych znaczeń. Natomiast Klorynda, umierając, daje świadectwo wiary i mocy Boga.

Od najmłodszych lat cechowała Kloryndę siła i umiejętność władania mieczem i łukiem. Nie dla niej były niewieście zajęcia, „[...] nad które więtszej mieć nie mogła męki” (pieśń II, oktawa 39). Nie wiadomo, w jaki sposób Klorynda została pasowana na rycerza. Opowieść Arseta, opiekuna bohaterki, mówi o jej królewskim pochodzeniu. Lecz Klorynda nie znała prawdziwej historii swego rodu, a narrator nie wspomina o jej wcześniejszych losach, z wyjątkiem stwierdzenia, że walczyła w Persji. Czy Arset, mimo ukrywania prawdziwego rodu bohaterki, poświadczał jej wysokie urodzenie, czy też została ona pasowana na rycerza za sukcesy na polu walki? Tekst Jerozolimy wyzwolonej nie odpowiada jednoznacznie na to pytanie.

Niejednoznaczne jest także źródło niezwykłego męstwa Kloryndy. Może być ono związane, jak sugeruje Goliński, z siłami nadprzyrodzonymi czy z opieką św. Jerzego ${ }^{22}$. Bohaterowie eposu nieraz korzystają z boskiej lub piekielnej pomocy. Waleczna dziewica z pewnością znajduje się w zasięgu działania sił nadprzyrodzonych, jej narodziny są cudem - jest białym dzieckiem czarnoskórych rodziców. Matka Kloryndy powierza ją opiece św. Jerzego, który „[...] dzikiemu litość dał źwierzowi, / I bystrej wodzie" (pieśń XII, oktawa 37), ocalając życie bohaterki. Święty ukazuje się także Arsetowi, zapowiada bliską śmierć Kloryndy, jednocześnie nakłaniając mężczyznę, by ten dotrzymał danego słowa i przekonał dziewczynę do przyjęcia chrześcijaństwa.

Cuda towarzyszące działaniom Kloryndy wskazują, że jej życiowa droga została wytyczona przez wyższą instancję. Niezwykłe narodziny i późniejsze ujarzmienie natury przez siły nadprzyrodzone zwiastują konwersję bohaterki, poświadczają jej przeznaczenie do życia w wierze Chrystusowej. Jednak Klorynda, w przeciwieństwie do Gofreda, nie jest świadoma czuwającej nad jej losem Opatrzności Bożej; dopiero tuż przed śmiercią pojawia się u niej religijna myśl. Podkreślmy, iż Jerozolima wyzwolona nie ukazuje Kloryndy jako osoby żarliwie pobożnej. Dziewczyna jest przede wszystkim rycerzem. Wiara nie określa w pełni bohaterki, jak to się dzieje w przypadku Gofreda. Bliższe związki wydaje się mieć Klorynda z ziemią niż z niebem. Jeżeli obcuje $z$ transcendencją, to zawsze za pośrednictwem natury.

Od najmłodszych lat to właśnie porządek natury, a nie cywilizacji, był bliższy jej sercu. Symbioza bohaterki z przyrodą doprowadziła nawet do sytuacji, w której się „[...] ludziom źwierzem zdała” (pieśń II, oktawa 40). Klorynda w walce najczęściej używa łuku, co w połączeniu z jej zamiłowaniem do łowów przywołuje obraz greckiej bogini-dziewicy Artemidy, która jest przede

\footnotetext{
20 Ibidem, s. 90.

21 P. Wergiliusz Maro, Eneida, tłum. T. Karyłowski, oprac. S. Stabryła, Wrocław 1981, s. 336-339.

22 J.K. Goliński, Między niebem a piekłem..., s. 139.
} 
wszystkim panią łowów i zwierzyny, władczynią przyrody, czasem traktowaną także jako bogini wojny (polowanie wiązało się z wojną). Najczęściej przedstawiano ją z łukiem i strzałami w otoczeniu dzikich zwierząt, takich jak: łabędź, jeleń, lew lub tygrys ${ }^{23}$. Podobieństwo postaci Kloryndy do Artemidy uwidacznia się chociażby w doborze zwierząt, które towarzyszą bohaterce Jerozolimy wyzwolonej. Jest to tygrys i lwica ${ }^{24}$. Zwierzęta te, w świecie starożytnych mitów należące do otoczenia Diany, mają także swoje znaczenie w symbolice chrześcijańskiej. Podwójność kontekstów, w których istnieją, wskazuje pośrednio na dwuznaczność postaci Kloryndy. Kreowana jest mianowicie na pogankę i pogromczynię chrześcijańskich rycerzy, ale otacza ją także opieka Boga i w ostatecznym rozrachunku przyjmuje chrzest, stając się dzieckiem Bożym. Dlatego też nie dziwi pozorna sprzeczność znaczeń, wypływająca z obecności symboli tygrysa i lwicy. Tygrysa w tradycji chrześcijańskiej utożsamia się z diabłem, który podstępem zwodzi ludzkie zmysły, niegodziwość przedstawia jako cnotę, przekonuje do grzechu pochlebstwami lub strachem i ukazuje człowiekowi to, co w rzeczywistości nie istnieje ${ }^{25}$. Można zatem pokusić się o odczytanie pogańskiej wiary Kloryndy w kategoriach diabelskiego działania, zwabiającego człowieka w swoje sidła za pomocą iluzji prawdy. Symbol lwa ma ambiwalentne znaczenie, które staje się widoczne w scenie spotkania Kloryndy z lwicą. Lew bowiem ucieleśnia złe moce, lecz jednocześnie może symbolizować zmartwychwstałego Jezusa ${ }^{26}$. Podobnie w Jerozolimie wyzwolonej lwica pojawia się jako drapieżne zwierzę, grożące śmiercią Kloryndzie. Jednak za sprawą boskiej interwencji nie tylko nie atakuje dziecka, lecz karmi go własnym mlekiem.

Drugi cud związany z Kloryndą można rozpatrywać jako reminiscencję mitologicznego, ale także biblijnego zdarzenia. Być może nieprzypadkowo autor Jerozolimy wyzwolonej sięga po dość popularny w różnych kulturach i religiach motyw ocalenia dziecka, którego wody rzeki nie zatopiły, ale wyniosły na brzeg (np. w mitycznych narracjach o Remusie i Romulusie czy Mojżeszu). Bowiem ten motyw, wpisany w biografię Kloryndy, a mający swoje warianty w dwóch ścierających się w Gofredzie porządkach religijnych, ujawnia - czego dotychczas nie zauważono w badaniach nad eposem Tassa-Kochanowskiego - egzystencję bohaterki w dwóch światach: pogańskim i chrześcijańskim.

Geneza postaci virago również sięga tradycji judeochrześcijańskiej i grecko-rzymskiej, które stworzyły opowieści o córkach boga wojny Aresa, o Amazonkach, o wojowniczej Kamilli z Ene$i d y$, o boginiach wojny - rzymskiej Bellonie i greckiej Atenie, która była też boginią mądrości.

23 Zob. V. Zamarovsky, Słownik mitologii greckiej i rzymskiej, tłum. J. Illg, L. Spyrka, J. Wania, Katowice 1998, s. 94-95 [hasło: Artemida].

24 Tygrys pojawia się na hełmie Kloryndy, lwica nakarmiła bohaterkę własnym mlekiem. Zwierzęta te bardzo często występują w staropolskiej twórczości jako uosobienie okrucieństwa i siły, jak np. u Mikołaja Sępa Szarzyńskiego w pieśni O Frydruszu, który pod Sokalem zabit od Tatarów Roku Pańskiego 1519 (zob. M. Sęp Szarzyński, Poezje zebrane, wydali R. Grześkowiak, A. Karpiński przy współpracy K. Mrowcewicza, Warszawa 2001, s. 52-54).

25 Zob. S. Kobielus, Bestiarium chrześcijańskie. Zwierzęta w symbolice i interpretacji. Starożytność i średniowiecze, Warszawa 2002, s. 322-324 [hasło: Tygrys].

$26 \mathrm{~W}$ tradycji biblijnej lew jest symbolem zaświatów i otchłani, jego pojawienie się oznacza śmiertelne niebezpieczeństwo. Z kolei historia o lwicach, które rodzą martwe potomstwo, ożywione dopiero tchnieniem ojca, kojarzy się ze zmartwychwstaniem Chrystusa - zob. M. Lurker, Słownik obrazów i symboli biblijnych, tłum. K. Romaniuk, Poznań 1989, s. 111-112 [hasło: Lew]. 
Również biblijne kobiety - Debora, Jael czy Judyta ${ }^{27}$ - stają się wzorami walecznych niewiast. Na kartach historii zapisały się także heroiczne czyny postaci takich jak Joanna d’Arc czy Baha-ad-Din, łuczniczka walcząca przy boku sułtana Saladyna ${ }^{28}$.

Nie jest więc w żadnym wypadku Klorynda bohaterką odosobnioną. Typ walecznej kobiety pojawia się w mitach i opowieściach od dawna ${ }^{29}$ i podług niego ukształtowana została postać bohaterki Jerozolimy wyzwolonej. Klorynda reprezentuje rzeczywiste kobiety, biorące udział w wyprawach krzyżowych, ale jednocześnie to postać odsyłająca do tradycji antyku i judaizmu. W niczym nie ustępuje rycerzom, nierzadko przewyższa ich swymi umiejętnościami, jej zadaniem nie jest wyłącznie stworzenie odpowiedniego tła dla chwały mężczyzn. W pełni niezależna w swych decyzjach, wzbogaca świat przedstawiony eposu o postać kobiety-wojowniczki, która może pretendować do miana heroiny. Tym samym konstrukcja postaci bohaterki wykracza poza najbardziej typowy sposób ujmowania sylwetek kobiecych w epopei.

Prawzorów kolejnej bohaterki epopei Tassa, Armidy, można szukać przede wszystkim w opowieściach o mitologicznych czarodziejkach Kirke i Medei. Podobnie jak poprzedniczki, reprezentuje Armida kobiecość drapieżną, niebezpieczną w swym uroku, zniewalającą zmysły i rozum. Świadoma własnej siły, ale także czerpiąca z doświadczenia swych antycznych sióstr, „[...] czynić więcej chce, niźli czyniły / Cyrce z Medeą mocą swej nauki” (pieśń IV, oktawa 86). Pod pozorem niewinnej i skrzywdzonej przez los kobiety kryje się manipulatorka, która do perfekcji opanowała grę słowem i własnym ciałem. Jej czarowi nie ulega jedynie Gofred, chroniony przez Boską Opatrzność, i Tankred, którego sercem rządzi miłość do Kloryndy. Nie tylko uroda była jej bronią. Nie można bowiem odmówić Armidzie chytrości, ale i inteligencji, doskonałego wyczucia sytuacji, dogłębnej analizy ludzkiego charakteru i umiejętności perswazyjnych ${ }^{30}$. Tasso, a za nim Kochanowski, konstruując postać Armidy, wyposażył ją w znajomość zasad sztuki wymowy. Miała ona świadomość, że powodzenie jej misji zależy od przychylności rycerzy, musiała sprawić, by uwierzyli w jej słowa. Wiedziała, że wiarygodność „[...] osiąga się wówczas, gdy mowa powoduje ich [słuchaczy - K.B.] wzruszenie"31.

Bohaterka sztukę perswazji opanowała perfekcyjnie. Zanim zabrała głos, już zjednała sobie wojowników pokorą i grzecznością („Do samej ziemie nisko się skłoniła”; pieśń IV, oktawa 38), a chwaląc Gofreda jako największego z rycerzy, kusiła go wizją jeszcze większej sławy. Z kolei świadoma, że pogańska wiara może przemawiać na jej niekorzyść, uprzedziła niechęć Gofre-

\footnotetext{
27 Zob. J. Baldock, Kobiety w Biblii, tłum. K. Lossman, Warszawa 2008, s. 81-83; 83-85; 196-199.

28 R. Pernoud, Kobieta $w$ czasach..., s. 24.

29 Zob. P. Żmudzki, Władca i wojownicy..., s. 165-178.

30 Postać Armidy z jej nieprzeciętną urodą i bystrym umysłem można z powodzeniem zestawić z kreowanym przez mizoginistów wizerunkiem „kobiety złowrogiej”. Odraza względem kobiet nie zawsze dotyczyła tylko kobiecego ciała. Krytykowano także ich charakter i ducha. Mizoginiści przestrzegali, że niewiasty są zdradliwe i chytre, często dobrowolnie zostają wspólniczkami diabła i wykorzystują swoją urodę, by zwieść i oszukać mężczyzn (zob. D. Gilmore, Mizoginia, czyli męska choroba, tłum. J. Margański, Kraków 2003, s. 84-112). W Armidzie można więc doszukać się cech diabolicznej kobiety z mizoginistycznych wyobrażeń.

31 Arystoteles, Retoryka, tłum., wstęp, komentarz H. Podbielski, [w:] Arystoteles, Dzieła wszystkie, t. 6: Polityka, Ekonomika, Retoryka, Retoryka dla Aleksandra, Poetyka, Zachęta do Filozofii, Ustrój polityczny Aten, List do Aleksandra Wielkiego, Testament, tłum., wstępy i komentarze M. Chigerowa i inni, Warszawa 2001, s. 307.
} 
da, powołując się na wspólnego Boga i wskazując na konieczność zadośćuczynienia krzywdzie. W jej (zmyślonej) historii nie brakowało wzmianki o śmierci rodziców, okrutnych i chciwych krewnych, zdradzie i ucieczce ${ }^{32}$. Pikanterii tej opowieści dodaje epizod mówiący o rzekomych wszeteczeństwach, których dopuściła się Armida. W jej opowiadaniu rozbrzmiewają akordy smutku i rozpaczy, straconych złudzeń, ale też nadziei. Podobnie jak Szatan kuszący Jezusa na pustyni, tak tessalska wiedźma roztaczała przed Gofredem obraz bogactwa i mocy: „[...] ty możesz mieć me państwo" (pieśń IV, oktawa 63), a z nim otwartą drogę do podboju Egiptu. Gdy jednak spotkała się z odmową, nie złożyła broni, lecz sięgnęła po inne środki - gniew i łzy. Emocje, którym dawała wyraz, były w rzeczywistości wykalkulowane - z pewnością świadcząc o jej nieprzeciętnym umyśle.

Łatwość, z jaką przychodzi bohaterce podbój męskich serc, można tłumaczyć jej urodą. W dawnych wiekach wierzono, że piękno fizyczne odzwierciedla piękno ducha ${ }^{33}$. Oczywiście nie zawsze uroda idzie w parze $\mathrm{z}$ dobrem, a antyczne pojęcie kalokagathos (kalos - piękny; agathos - dobry) może okazać się zwodnicze. Czasem dochodzi do sytuacji odwrotnej - to, co odpychające, okazuje się pożądane. Nawet - wydawałoby się - trudną do rozstrzygnięcia kwestię brzydoty ukrzyżowanego Chrystusa udało się rozwiązać. Św. Augustyn tłumaczył, że umęczone i odrażające ciało Jezusa kryje wewnętrzne piękno, jest wyrazem Jego człowieczeństwa, poświęcenia i chwały ${ }^{34}$. W przypadku Armidy, która ostatecznie przyjęła chrześcijaństwo, można chyba mówić o współistnieniu piękna zewnętrznego i duchowego ${ }^{35}$.

Nim jednak dojdzie do nawrócenia bohaterki, jej uroda służy szatańskiej sprawie. Lucyfer, za pośrednictwem Hidraota, czarnoksiężnika i wuja bohaterki, posłał ją do walki z chrześcijanami, wiedząc, że potrafi oczarować rycerzy. Nie mylił się. Jej działania wywarły wpływ na przebieg walk, niemal doprowadziła do otwartego buntu przeciwko Gofredowi, zaś chrześcijanie utracili wielu rycerzy, którzy - omamieni jej wdziękami - opuścili pole walki.

Omawiając postać Armidy, nie można pominąć tych zdolności bohaterki, które w eposie Tassa pozostają nieco mniej wyeksponowane niż jej miłosne perypetie z Rynaldem i innymi rycerzami. Magia, czyli znajomość uroków i zaklęć, jest bowiem najpotężniejszą bronią Armidy, na co wskazuje jej wuj:

\section{[...] w postawie}

Mdłej białejgłowskiej z męskim sercem chodzisz,

I już mię w trudnym czarnoksięskim prawie

I w czarowniczej nauce przechodzisz.

(pieśń IV, oktawa 24)

\footnotetext{
32 Zob. T. Tasso, Gofred..., s. 154-162 (pieśń IV, oktawy 39-64).

33 Pisze na ten temat H. Dziechcińska, Kobieta w życiu i literaturze XVI i XVII wieku, Warszawa 2001, s. 59.

34 Zob. Historia brzydoty, red. U. Eco, Poznań 2007, s. 23-24, 43-49.

35 Dusza Armidy „[...] składa się z kilku niejako pokładów, które z czasem przenika i przepala do samego dna żywiołowa miłość [...]” (R. Pollak, „Goffred” Tassa-Kochanowskiego..., s. 128), dlatego jej postawa, w tym także akt przyjęcia chrześcijaństwa, nie może być jednoznacznie (i zbyt pochopnie) oceniona.
} 
Armida, podobna do mitycznej Kirke, zmienia mężczyzn w zwierzęta. Obcuje ze śmiercią niczym Medea, przywołując duchy. Utrzymuje naturę w stanie nieustannego rozkwitu niby Kalipso. Sprowadza na ziemię ciemności jak Louhi. Armida obdarzona jest zdolnościami swych poprzedniczek, a jednocześnie jest od nich potężniejsza ${ }^{36}$.

Magia Armidy nierozerwalnie wiąże się z siłami przyrody. Nie są to jednak wyłącznie niszczycielskie moce. Czarownica tworzy własny świat, kierując siłami wegetacyjnymi, niczym mityczna Terra Mater. Wyczarowała krainę rozkoszy, szczęśliwości i beztroski, w której króluje młodość i zmysłowość. W stworzonej przez Armidę rzeczywistości rządzą prawa miłości, a nie religii czy polityki. Ten kreacyjny zabieg Armidy świadczy o tym, że bohaterka, podobnie jak wielu innych, chciała znaleźć dla siebie miejsce, w którym mogłaby żyć w zgodzie z sobą samą. Arkadia jest bowiem ucieczką od świata, w którym przyszło człowiekowi żyćc ${ }^{37}$. Właśnie dlatego bohaterka stworzyła miejsce niedostępne dla przygodnych wędrowców, skryte przed oczami tych, którzy próbowali wpływać na jej decyzje ${ }^{38}$, zerwała kontakty ze światem zewnętrznym. Wiedziała, że zarówno poganie, jak i chrześcijanie potępiliby jej związek z Rynaldem. Ucieka zatem wraz z ukochanym do wyczarowanej krainy szczęścia, która jednak, choć bardzo realistyczna, okazuje się fantazją i iluzją rzeczywistości.

Orfeusz śpiewem wyczarował własną Arkadię, aby w ten sposób uciec przed rzeczywistością, która odebrała mu Eurydykę, i znaleźć ukojenie ${ }^{39}$. Armida czarami stworzyła swój azyl na ziemi, aby żyć w nim z Rynaldem. Jednak ani Orfeuszowi, ani Armidzie się nie powiodło. Armida wprawdzie nie umiera, ale opuszcza ją ukochany mężczyzna, a ona uśmierca swoją Arkadię. Bohaterka jest świadoma tego, jak łatwo piękna kraina może przeistoczyć się w miejsce straszne ${ }^{40}$. Ślady dawnych nieszczęść i pogrzebanych nadziei odnaleźć można na murach jej pałacu; przykładem jest chociażby historia niespełnionych ambicji Kleopatry i Antoniusza. Nic dziwnego, że pomna losów egipskiej królowej bohaterka pragnie zabezpieczyć się przed zagrożeniem ze strony świata zewnętrznego, stawiając pułapki mające powstrzymać każdego, który zechce zakłócić jej spokój. Podróżnych wabią piękne dziewczęta, zachęcające do cielesnych rozkoszy

\footnotetext{
36 W niewielkim stopniu Armida natomiast realizuje stereotypowy obraz czarownicy (choć potrafi latać i zamieniać ludzi w zwierzęta). Nie pożera dzieci ani nie chrzci ich w imieniu szatana, nie jest kochanką diabła, nie bezcześci sakramentów świętych, nie sprowadza chorób (jeśli nie liczyć miłosnej gorączki, choć właściwie nie czarami pozyskała serca rycerzy, a urodą i wdziękiem), nie niszczy plonów, nie uczestniczy w sabatach czarownic. Cechy i działania czarownic opisane zostały w dziele: J. Sprenger, H. Kraemer: Młot na czarownice, tłum. S. Ząbkowic, oprac. J. Paprocka, Wrocław 2000.

37 Zob. A. Krzewińska, [hasło] Arkadia, [w:] Słownik literatury staropolskiej (średniowiecze, renesans, barok), red. T. Michałowska, Wrocław 1990, s. 50-55.

38 Armida mówi: „Jam nic nie winna, wszystko to stryj sprawił, / Wszystko to sprawa mego opiekuna: / On płeć mdłą w drogę daleką wyprawił, / On ze mnie naprzód uczynił bieguna. / [...] / Przeto czynię li co nieprzystojnego, / Wszystko to z stryja przyczyny mojego" (pieśń XVI, oktawa 73). Słowa bohaterki pokazują, jak wielką rolę w jej życiu odgrywała wola wuja, czarnoksiężnika Hidraota, jak chęć spełnienia jego życzeń wpływała na podejmowane przez bohaterkę decyzje.

39 N.W. Bernstein, Locus Amoenus and Locus Horridus in Ovid's Metamorphoses, „Wenshan Review of Literature and Culture" 2011, vol. 1, s. 77.

40 Zob. E.R. Curtius, Literatura europejska..., s. 191-209.
} 
i próbujące przemienić wędrowców w rycerzy Miłości ${ }^{41}$. Drogi do Arkadii strzegą drapieżniki: smok, lew i niedźwiedzica ${ }^{42}$, a źródło wody kryje w sobie jad. W symbol źródła wpisana została ambiwalencja - $\mathrm{z}$ jednej strony jest $\mathrm{w}$ nim woda życia, $\mathrm{z}$ drugiej strony jego powstanie wiąże się z mrocznymi siłami ziemi. Źródlana woda może być zarazem słodka, jak i gorzka ${ }^{43}$. Autor Jerozolimy wyzwolonej wyzyskał dychotomię znaczeń, by stworzyć źródło skrywające truciznę.

Paradoksalnie miłość, która miała odciągnąć rycerzy chrześcijańskich, w tym Rynalda, od Boga, okazała się równie groźna dla Armidy. Bohaterka nie przewidziała, że sama wpadnie w sidła Amora. Podobnie jak Medea, musiała Armida odnaleźć się w nowej roli - w roli kobiety, która kocha, prawdopodobnie po raz pierwszy w życiu. Z nieprzyjaciółki staje się bohaterka kochanką, która wykorzystując swoje mroczne moce w służbie miłości, zamyka Rynalda w złotej klatce stworzonej przez siebie Arkadii.

Jednak Armida nie potrafiła zatrzymać przy sobie rycerza powodowanego rycerską dumą (i wolą Bożą). Bohaterka stawia na szali własną godność i rzuca się w szaleńczą pogoń za ukochanym. Na próżno - Rynald nie uległ ani jej czarom, ani łzom. Czując się zlekceważona, wpada we wściekłość. Armida, władczyni miłości konkurująca z Afrodytą, staje się władczynią zemsty, siostrą Erynii, i jako taka poprzysięga ścigać Rynalda w piekle i na ziemi, obiecuje swe bogactwo i urodę temu, który pozbawi rycerza życia ${ }^{44}$. Niewiasta idzie w ślady swojej poprzedniczki, Medei, która także ukojenia szukała w zemście. Jednak u Tassa rezultat walki nienawiści z miłością nie jest jednoznaczny.

Owa niemożność pogodzenia się z własnym losem i z odtrąconą miłością, ale także bezsilność, której doświadczyła, być może po raz pierwszy, popycha bohaterkę do targnięcia się na swoje życie. Gdy zawiodły ją magia i piękno, sięga po radykalne środki, wierząc, że „[...] ranę leczyć muszę raną; / Rana od strzały - od miłości ranę / Zgoi i zdrowia od śmierci dostanę" (pieśń XX, oktawa 125). Powtarza tym samym gest Dydony zakochanej w Eneaszu. Tasso zrywa z tą konwencją: Armida nie umiera jak Dydona, ale też nie ucieka jak Medea. Brak krwawego końca jest tak niespodziewany, że aż budzi sprzeciw ${ }^{45}$. Choć epopeiczne poprzedniczki Armidy musiały zginąć, ona przeżyła, a na dodatek została obdarzona miłością jednego z najdzielniejszych rycerzy Gofreda ${ }^{46}$. Losy Armidy ukazują podwójny system wartości, leżący u podstaw Jerozolimy wyzwolonej. Z jednej strony jest to duch podboju i krucjaty, z drugiej - miłości chrześcijań-

\footnotetext{
41 B. Cieszyńska, Okna duszy..., s. 161.

42 W sztuce średniowiecznej smok, lew i niedźwiedź symbolizują złe moce - zob. M. Lurker, Słownik obrazów..., s. 219-220; 111-112; 135-136 [hasła: „smok”; „lew”; „niedźwiedź”].

43 Zob. ibidem, s. 283 [hasło: „Źródło”].

44 Zob. T. Tasso, Gofred..., s. 535-543 (pieśń XVI, oktawy 43-66).

45 Krzyżanowski wspomina jednego z epigonów Tassa, który „uśmiercił” Armidę, zob. J. Krzyżanowski, „Jeruzalem wyzwolona" Tassa-Kochanowskiego..., s. 387.

46 Mimo że Rynald opuścił Armidę, darzył ją szacunkiem i miłością. Odtrącenie bohaterki nie wynikało z braku uczucia - Rynald nie rezygnuje z miłości, nie potępia bohaterki (jedyny zarzut, który jej stawia, to brak umiarkowania zarówno w miłości, jak i w nienawiści). Wie jednak, że w tym momencie jego czyny muszą być podporządkowane woli Chrystusa. Gdy widzi rozpaczliwe położenie Armidy w czasie rozstrzygającej bitwy, podąża śladem ukochanej i ostatecznie ratuje jej życie. Będąc wiernym sługą, Rynald obiecuje bohaterce pomoc w odzyskaniu tronu.
} 
skiej, miłosierdzia i wybaczenia ${ }^{47}$. Motyw miłości wiedźmy tessalskiej i rycerza Chrystusowego pokazuje, że sprzeczność kryjącą się w człowieku (i w świecie) da się usunąć. Można pozostać Bożym wybrańcem i jednocześnie korzystać z uroków doczesności ${ }^{48}$.

Janusz Goliński twierdzi, że historia Rynalda i Armidy to w istocie opowieść o zwycięstwie miłości, której bliżej jest do amor sacer niż amor profanus ${ }^{49}$. Jednak czy na pewno? Być może Rynald, który obronę wiary i miłość do Boga stawia nad uczuciem do Armidy, realizuje ideał miłości świętej. Ale Armida? Pod maską nawróconej kobiety, za zasłoną amor sacer, kryje się wciąż żywa zmysłowość. Armida nie woła, jak Klorynda: „Proś Boga za mię i grzechem spluskaną / Oczyść krztem świętym i zbroń od pokusy" (pieśń XII, oktawa 66), nie szepcze z wdzięcznym uśmiechem „Niebo-m osięgła, nieba-m dostąpiła” (pieśń XII, oktawa 68). „Niech się - powiada - twoja wola stanie, / Wszystko uczynię na twe [Rynalda - K.B.] rozkazanie" (pieśń XX, oktawa 136) - w ten sposób Armida przyjmuje chrzest. Nie takie słowa wypłynęłyby z ust szczerze skruszonej konwertytki. One nie świadczą o miłości do Boga - jedynie o nieograniczonym uczuciu, jakim darzy ukochanego. To Rynald, nie Bóg, jest adresatem tych słów. Słowa Armidy: „Niech się twoja wola stanie”, jak echo powtarzają słowa Modlitwy Pańskiej. Jednocześnie są kontynuacją wypowiedzianej wcześniej prośby: „Ciebie, ach! nieboga, / Ciebie, ach, mieć chcę samego za Boga!” (pieśń XVI, oktawa 46).

Armida miała największy wpływ na rozwój akcji. Konsekwentnie realizowała plan zmierzający do osłabienia chrześcijan. Większość epopeicznych bohaterek olśniewała pięknem fizycznym. Uroda była ich atrybutem, ale przede wszystkim usprawiedliwieniem afektu, jaki wzbudzały w mężczyznach. Dla Armidy uroda jest środkiem pozwalającym odnieść sukces. Jej działania determinują zachowanie zarówno rycerzy chrześcijańskich, jak i pogańskich. W ostatniej pieśni Jerozolimy wyzwolonej poganie walczą z Rynaldem w imię Armidy, a nie Allacha. Jednocześnie bohaterka przełamuje schematy obowiązujące w tradycyjnym eposie. Nie dołącza bowiem do swych poprzedniczek-samobójczyń. Tasso pozwolił jej połączyć się z ukochanym, co jest symptomem zmian wizerunku epopeicznych bohaterek.

Nie tylko Armida próbuje zwieść otoczenie. Także Erminia, następna bohaterka Jerozolimy wyzwolonej, ukrywa swą miłość do Tankreda, rycerza obcej wiary, który pozbawił tronu jej ojca, a ją wziął do niewoli. Erminią targają sprzeczne emocje. Tankred został uratowany dzięki jej poświęceniu - to obcięte warkocze Erminii tamowały krew, sączącą się z ran rycerza. By w pełni docenić ofiarę bohaterki, trzeba pamiętać o tym, że warkocz był oznaką dziewictwa ${ }^{50}$. Bohaterka, która była zdecydowana zachować cnotę nawet za cenę wolności (błagała bowiem Tankreda, gdy ten zdobył jej królestwo - „Proszę, zwyciężco, abyś się zmiłował, / Nie daj żywota, nie daj mi wolności, / Tylko mi obroń panieńskiej czystości!"; pieśń XIX, oktawa 93), dobrowolnie obcina warkocz, symbol czystości. Można jednak inaczej rozumieć gest Erminii. Wiedząc o nieustannej walce cnoty z namiętnością, toczącej się w sercu bohaterki, nie można całkowicie od-

\footnotetext{
47 A. Kalewska, „Gofred” Tassa-Kochanowskiego..., s. 118.

48 B. Cieszyńska, Okna duszy..., s. 148.

49 Zob. J.K. Goliński, Między niebem a piekłem..., s. 137.

50 Zob. Z. Gloger, Encyklopedia staropolska ilustrowana, t. 4, Warszawa 1974, s. 102 [hasło: „warkocz”].
} 
rzucić i takiej hipotezy, że obcięcie warkocza oznaczało zwycięstwo pożądania. Autor kończy historię Tankreda i Erminii, gdy oboje docierają do Jerozolimy, a bohaterka czuwa przy rannym rycerzu, nie opuszczając go na krok. Jak potoczą się jej dalsze losy? Być może jej gest jest proroczy i wkrótce zostanie żoną Tankreda, a może po prostu przestanie strzec cnoty za wszelką cenę i da się ponieść namiętności.

„Cnota i miłość, dwaj rycerze mężni, / Spierają się w niej - a oba potężni” (pieśń VI, oktawa 70). Jeden wyrzuca Erminii, że chce oddać swoje dziewictwo z własnej woli po tym, jak udało się mu ustrzec ją przed wszelkimi niebezpieczeństwami w niewoli, drugi pyta: „Co za grzech miłować?” (pieśń VI, oktawa 73) i roztacza przed bohaterką wizję rychłego zamążpójścia. Raz kontrolę nad Erminią przejmują uczciwość i cnota, a raz miłość popychająca ją do szaleństw, a nawet zbrodni. Ostatecznie dziewczyna nie decyduje się wprowadzić w życie swojego morderczego planu, jednak sam fakt, że bohaterka rozważała otrucie Arganta, świadczy o potędze pożądania. Nie bez powodu narrator nazywa uczucie bohaterki do Tankreda „złą miłością”, gdyż ma ono głównie cielesny wymiar, ukazuje skrywaną, mroczną stronę osobowości bohaterki. Na tle pozostałych postaci kobiecych Erminia wydaje się najbliższa stereotypowi słabej i niezdecydowanej kobiety. Motyw walki cnoty z namiętnością, który kształtuje jej wizerunek, koresponduje z petrarkistowską koncepcją miłości: „Petrarka wyznaczył miłości perspektywę metafizyczną, lecz zmierzanie ku ostatecznemu celowi osadzone zostało w świecie ludzkich zmagań, konfliktu między sensualistyczną naturą człowieka a świadomością wyboru wyższych wartości”51. Droga ku transcendencji wiodła poprzez miłosne uniesienia, a walka ciała z duszą była jednym ze sposobów osiągnięcia moralnej doskonałości52. Metafizyczny aspekt miłości Erminii do Tankreda wyraża petrarkistowskie podejście do kondycji człowieka.

Erminia jest nie tyle kobietą, którą targają sprzeczne emocje, ile człowiekiem zmuszonym mieć się ciągle na baczności, by nie zboczyć z właściwej drogi życia. Jej losy stają się parabolą ludzkiego przeznaczenia ${ }^{53}$. Jednakże funkcja Erminii w Jerozolimie wyzwolonej nie wychodzi poza konwencjonalne, określone już w starożytności, zachowania kobiet. Odgrywa więc bohaterka rolę nieszczęśliwie zakochanej kobiety, która dzięki miłości i poświęceniu ratuje (na pewnym etapie rozwoju akcji) życie ukochanemu. Jak Medea Jazonowi, Kalipso Odyseuszowi, tak Erminia Tankredowi pomaga i oddaje serce.

Działania postaci kobiecych w Jerozolimie wyzwolonej przestały być marginalne i epizodyczne, a sceny, w których się one pojawiają, nie mają jedynie waloru estetycznego; ich zadaniem nie jest wyłącznie bierna obecność u boku mężczyzn. Bohaterki poprzez swe decyzje wpływają na losy cudze i własne. Tasso kobiece postaci stworzył w ten sposób, że stały się one pełnoprawnymi uczestniczkami zdarzeń, mając do odegrania nieporównywalnie większą rolę, niż by to wynikało z tradycji epopeicznej. Podejmowane przez bohaterki eposu decyzje wpływają na rozwój akcji.

\footnotetext{
51 J. Kotarska, Petrarkizm w poezji polskiego renesansu i baroku, [w:] Studia porównawcze o literaturze staropolskiej, red. T. Michałowska, J. Ślaski, Wrocław 1980, s. 31.

52 Ibidem, s. 31.

53 O mistycznym doświadczeniu człowieka w Jerozolimie wyzwolonej pisała A. Kalewska, „Gofred” Tassa-Kochanowskiego..., zob. zwłaszcza s. 115-118.
} 
Na znaczeniu zyskały wątki romansowe, które przeplatają się z batalistycznymi, tworząc spójną całość. Świat przedstawiony eposu bez Erminii, Armidy i Kloryndy byłby znacznie uboższy.

\section{Between tradition and novelty. The role of female characters in the epic poem La Gerusalemme liberata (Jerusalem Delivered) by Torquato Tasso}

\section{The Summary}

The article's aim is to present the main female characters of the epic poem La Gerusalemme liberata (Jerusalem Delivered) by Torquato Tasso (translation by Piotr Kochanowski), i.e. the witch Armida, the warrior-maiden Clorinda and the princess Erminia. Their behaviour is based on the symbolic, historical and social contexts. The article tries to answer the question concerning the functions women had in Tasso's poem. The author created female characters in such a way that they became the leading participants of the events and had much more prominent roles to play than expected from women in this kindle of poems. The decisions taken by the heroines influence the course of events.

słowa kluczowe: epopeja staropolska, Torquato Tasso, Piotr Kochanowski, Gofred abo Jeruzalem wyzwolona, wizerunek kobiet

keywords: old Polish epic, Torquato Tasso, Piotr Kochanowski, Gofred abo Jeruzalem wyzwolona (Jerusalem Delivered), image of women 